\title{
MODELLING THE COGNITIVE MAP OF THE CITY CENTRE: A CASE STUDY OF BUCHAREST, ROMANIA
}

\author{
Robert Cristian Stoiculescu
}

University of Bucharest, Faculty of Geography, Bucharest, Romania

\begin{abstract}
The city centre is a place of emblematic significance for the urban community, where the essence of the sociourban identity is condensed. The centre of the post-socialist city has travelled varied meanings and extensions that have been perceived differentiated between sequences of generations. Functionalist stratifications have induced in the collective imagination a superposed series of centres: historical, tourist, economic, cultural, each dilating or contracting the urban centre's limits, depending on the significance that has been inoculated to the receiving subject. It was starting with year 1977 that the political will imposed the achievement of a new "Civic Centre" which was desired to be an imprint of the cultural and scientific progress of that moment. Communist interventions attempted to uniform the urban landscape by inserting visual and emotional mutations. The present analysis regards the perception of Bucharest's centre and offers a perspective on the relation between residents and place, considering that human behaviour indicates some inconsistencies related to the urban planning of the post-socialist city that deals with intense processes of identity transformation.
\end{abstract}

Key words: Perception, Identity, Urban image, Behavioural geography, Environmental cognition.

Article Info: Manuscript Received: May 9, 2012; Revised: October 28, 2012, Accepted: November 15, 2012; Online: November 30, 2012.

\section{Introduction}

The city centre appears in the collective imagination as the best defined part of the city after each resident's neighbourhood. It's perceived by everyone, given that it provides unity and coherence to the urban entity (Bailly \& Scariati, 1990:59). Also, the centre or "city's heart" (Macavescu, 1973) is often an anchor in the individual cognitive mapping, in moving through the urban space and in the contextual orientation.

A significant segment of studies within behavioural geography is associated with urban studies regarding the degree in which people are certain about their location, based on a reference system which is often formed of external landmarks. In a geographical sense, people can feel attached to places based on their mobility, the attractiveness of the location and familiarity. Therefore, most studies in this field of research have focused on the

\footnotetext{
* Correspondence address:

Address: University of Bucharest, Faculty of Geography, 1, Nicolae Bălcescu Avenue, 010041, Bucharest, Romania.

Telephone: +4.0720 .507 .278$

Email: robertstoic@yahoo.com
}

neighbourhood or the urban community. This peculiarity is due to the fact that people tend to show a higher attachment towards the neighbourhood and the community in comparison to other parts of the city (Tuan, 1976 apud Tuan, 2002) and the residence's length determines the intensity of place attachment. "Home" is a central place in experiencing the urban space, being the reference point of the inhabitant (Relph, 1976 apud Seaman, 2008:41). The neighbourhood is perceived as a homogenous sociospatial structure, shaped by architectural, social or administrative limits (Moser, 2009:99) representing the transition from the intimate home to the city and its different parts.

In everyday language the word "centre" is frequently used, which shows an awareness of it and its tracking in the urban structure. It has an intense employment in the vocabulary of the local community's members: "I'm going into the city centre", "I was in the centre/downtown". Also items meant to locate the boundaries of the centre are used: "building $\mathrm{x}$ is at the centre" or "building $\mathrm{y}$ is close to the centre" (Damian et al., 1976:657). Moreover, the word "centre" is replaced with "city" (e.g. "I'm going into the city"). While the subject is already located in the urban area, he wants to emphasize this fact, but 
even more, "the city" refers to its centre, an expression widely recognized by the community to which the individual is associated. This expression is used to mark the departure from the family's space (Bailly, 1977), here appearing a demarcation of the two spaces: space of safety (personal or intimate home) and outer space (space of exposure). Using the two terms also marks the existence of a behavioural rupture which is imposed by the distance from the centre, the "city" being perceived as being outside the residence area.

The history of researching and planning the urban centre reveals multiple methods of evaluation and typological classification. For example, Rengert and Pelfrey (1997:196) evaluated Philadelphia's centre in the perspective of cognitive maps. The process of appropriating spatial information is defined in terms of "cognitive mapping process" which consists of four elements: the actor, the environment, "environmental cognitions" (individual information received from the environment) and "behavioural response to the environment" (the actor's attitude in regard to the environment). The registration, coding and mental reordering of the environmental information are highly complex and involve differentiating the perception of the same place and phenomenon between individuals although there is a certain homogenization within social groups (Bailly \& Béguin, 1982). Another study that strengthens the evaluation method used for Bucharest's centre was conducted in 2004 by Tallon et al. Without seeking an explicit delineation of the urban centre, in this study are presented features of urban centres that were identified through a sociological survey of the inhabitants' attachment to the city centres of Bristol and Swansea. During this study were investigated attitudes, respondents stating the advantages of living in urban centres and argued the motivation of relocating in these places (Tallon et al., 2004:779). Residents considered, in a hierarchical order, that a positive aspect of the centre is the proximity of services and facilities, the location's attractiveness, followed by the quality of housing, the short distance to work and friends and the presence of leisure opportunities.

For Romania, a significant step in analysing problems of the city centre took shape in the '70s. Firstly, it appeared the question of assessing the residents' perception regarding Bucharest. Using the principles of urban image analysis that were introduced by Lynch (1960) a team of researchers from the Laboratory of Urban Sociology in Bucharest Municipality have produced, together with the Institute of Architecture and Urbanism "Ion Mincu", the first pilot researches which included mental mapping Bucharest's centre. Socio-urban planning and the policy of food rationalization determined the structuring of a communist city centre that was shaped by landmarks which reflected everyday's problems of people facing the lack of a minimum urban housing comfort. Consequently, the development of studies in this direction divided the centre in concentric areas, with a main denser structure, called "nucleus" which was followed by a second ring called "fringe" that had a broader unfolding around the city's central nucleus, where the central functions were combined with residential ones. Later were published several studies produced by sociologists (e.g. Buică et al., 1995) and architects. The theme of assessing the urban centre's perception and the behaviour of urban dwellers with this part of the city was continued by architects and urban planners, including Sandu (200o) and Pascariu (2005). In addition, people's perception of the city's centre was one element of the General Urban Plan (Sandu, 2000).

This study's objective is to identify the limit of the perceived city centre of Bucharest and the cause of its organisation around significant urban landmarks, given that the central place is opened towards all the city's inhabitants because it encompasses places of public interest, located at the intersection of cultural, social and economic purposes. Moreover I focused on its structuring in relation to the boulevards which polarise the urban reference elements and new buildings like the People's House (or the Parliament Palace) the changed the centre's extension in the last decades. Another objective of this paper is to delineate between the perception of people living in different neighbourhood who pull the centre's limit in the direction of their residence.

These considerations led to structuring the study's hypothesis according to which the centre reflects the image of the society that modelled it, in a mosaic form, since it retains the contribution of each community and generation. Depending on the particular socio-spatial structures that perceive the urban centre there are constructed different behaviours, attitudes, feelings that are related to the individual and collective memory of this area. I also considered that respondents which are belonging to different neighbourhoods of the city tend to perceive space similarly; a fact which sets its mark on the degree of expansion or contraction of the urban centre's limits and on its development directions.

\section{Methodology}

The evaluation of the collective imagination construction started from the idea that "centrality" represents the attribute of an element (object or place) located in the city's centre. The object of place will generally be named "landmarks" which were 
associated in the applied questionnaire the attributes of: centrality, non-centrality, imprecise location and unknown. The field survey was conducted through a questionnaire intended to allow the identification of several landmarks' position in relation to the perceived city centre. The respondents classified, based on a table (or matrix of choices), 94 landmarks from across the city, depending on four variables: 1) the landmark is in the city's centre; 2) the landmark is not in the city's centre; 3) the landmark is unknown; 4) the landmark is unclearly located. The questionnaire was conducted during $20^{\text {th }}$ April and $20^{\text {th }}$ May 2011 on a sample of 200 inhabitants of the six sectors in Bucharest.

The population sample (Table 1) includes a high percentage $(79 \%)$ of respondents who indicated to have high education, being located mostly in the northern part of the capital, in Militari, Drumul, Taberei, Balta Albă-Titan neighbourhoods, in opposition to inhabitants from Rahova and Ferentari who are mostly unemployed and graduated the lyceum or a professional school. This situation can be explained by the questionnaire's complexity which required respondents to be interested in the issues of the city's centre. Hence, of the 427 applied questionnaires, only 200 were validated. Respondents didn 't have a cartographic support on which to locate the landmarks defined by centrality, therefore the questions appealed to the individual memory of Bucharest's configuration. In addition, the population sample is characterised by a long residence period in Bucharest, which is evident in for the group of 26-45 years.

For this questionnaires were used 94 landmarks that are distributed from $\mathrm{Km}$ o (central point) of the city (the farthest landmark being located at $4 \mathrm{~km}$ from it), given that the radius of Bucharest municipality from this point up to its administrative limit is between $4,75 \mathrm{~km}$ and $11,5 \mathrm{~km}$. Landmarks were chosen according to notoriety, the orientation in the visual field, with a relatively equal distance between them. Also, one can distinguish two categories of landmarks: those located along major roads, which have a greater legibility (Lynch, 1960) and those which are placed in the secondary urban tissue between major roads, but these are also well known in this urban area.

That maps which are illustrating the perceived centre of Bucharest were created with ArcGis 9.3 software, using the interpolation function that ensures a higher accuracy and facilitates the geostatistical interpretation and spatial representation. The method allows representing the spatial complexity of the relationship between population and environment, by providing an appropriate analytical tool (Ostermann, 2009:16). Interpolation integrates the principle of autocorrelation between geographical elements (close objects tend to become equal compared to distant objects), in this case the landmarks that were digitized on a map to which it was associated a geographical reference.

Table 1. Data regarding the statistical population sample used in evaluating the perception of the urban centre

\begin{tabular}{|l|c|c|}
\hline \multicolumn{2}{|c|}{ Variable } & $(\%)$ \\
\hline \multirow{4}{*}{$\begin{array}{l}\text { Length of } \\
\text { residence in } \\
\text { Bucharest (years) }\end{array}$} & $0-5$ & 11.1 \\
\cline { 2 - 3 } & $6-10$ & 15.2 \\
\cline { 2 - 3 } & $11-25$ & 13.6 \\
\cline { 2 - 3 } Respondent's age & $26-45$ & 35.4 \\
\cline { 2 - 3 } (years) & $>46$ & 24.7 \\
\cline { 2 - 3 } & $18-25$ & 15.3 \\
\hline \multirow{4}{*}{ Occupation } & $26-45$ & 44.5 \\
\hline & $46-60$ & 31.1 \\
\cline { 2 - 3 } & $>60$ & 9.1 \\
\cline { 2 - 3 } & student & 10.5 \\
\cline { 2 - 3 } & employed & 60.3 \\
\cline { 2 - 3 } & unemployed & 2.4 \\
\cline { 2 - 3 } & retired & 13.4 \\
\hline \multirow{4}{*}{ Education } & other & 13.4 \\
\cline { 2 - 3 } & secondary school & 0.5 \\
\cline { 2 - 3 } & lyceum & 16.3 \\
\hline & professional & 3.8 \\
\cline { 2 - 3 } & school & 79.4 \\
\hline
\end{tabular}

The geometric analysis of the centre through the "Natural Neighbour" interpolation method integrates as variable the location of the landmark's numerical value from a shape file of point type. From this interpolation results a raster which illustrates the spatial distribution of a geographic phenomenon. Each raster cell is associated with a specified value that is identified in comparison with the one from a fixed point (Niţu \& Crăciunescu, 2009:14). It consists of approximating the value of intermediate points which are aligned in the basis of common characteristics across an isoline. These "isolines of centrality" (Damian, 1973) mark thresholds along the city centre. The central area is bounded by the isoline of $50.1 \%$ (of the total answers) which represents the ratio between the positive answers of the point (landmark) and the total answers on that specific point. Two other rings have been delineated within the centre that should highlight the internal structure of the centre's image, "with three sealed concentric layers that contain image properties which correspond to the physical attributes" (Damian et al., 1976:659). This classification on three thresholds was chosen from previous analyses during which were 
identified the following areas: nucleus (corresponding to the $85 \%-100 \%$ ), central area (between $75 \%-85 \%$ ) and centre's prominences (between $51 \%-75 \%$ ).

\section{Results and discussions}

A first aspect that was identified on the final cognitive maps is that they contain distortions of space caused by an insufficient knowledge of the whole area from the resident's point of view, the overestimation of certain places because of a better familiarity or because of a certain preference for that place. Another reason is the "inferential structure" (Boncu, 2008:15) based on which the respondent intervenes upon the space's components through the addition of non-existent elements in the real plan, but which are justified in the mental logic. I also noticed that there is variability with the centre's deployment, depending on the analysis' scale (respondents across the city or just from neighbourhoods) which is reflected on the level reached by the landmark's values.

Figure 1 presents the "isolines of centrality" which resulted from interpolating the value of the landmarks which were indicated by the entire statistical sample. The numbers from 1 to 8 represent landmarks located along major axes of the city which are complemented by the People's House.

The city centre which was shaped by all the survey's subjects is being profiled at the intersection of major north-south and west-east roads. This contact marks the geometric centre of the city and it reaches the extreme north point in Piaţa. Romană, the southern one is placed in Piața. Unirii, the western landmark is located in Piața. M. Kogălniceanu and in east Piaţa. C.A Rosetti. As for the cognitive map, the centre consists of several nuclei (e.g. one that overlaps the protection area of historical, architectural and urban values which forms the historical centre as it was delineated through the General Urban Plan of the Capital in 200o). This central nucleus is surrounded by fringes which have a tentacle expansion on the radial traffic arteries.

The major axes of the city are elements which order the landmarks and form the urban centre. They have a higher frequency of crossing and are concentrating a multitude of landmarks of visual value. Structuring the city's central image is determined by the two major axes of the city (northsouth/west-east) along which are aligned the values of axial landmarks; "their value increases constantly from the edge towards the nucleus, inside which it forms a level of maximum values".

From this point of view, using the term introduced by Lynch, "axial landmarks have an excellent legibility, unlike the non-axial ones from outside the nucleus, which ordering [...] presents considerable difficulties" (Damian et al., 1976:659). Everyday urban legibility consists in the ability of the urban space, or the landmarks in this particular case, to be easily observed. Landmarks are for the receiving subject (resident or occasionally passenger/tourist) visual markers of mental structuring and markers of identity. Axial landmarks are well defined and outlined in the cognitive landscape of the receivers. In the current analysis it has a significant importance in structuring and defining the city's central area, because landmarks become composing elements of

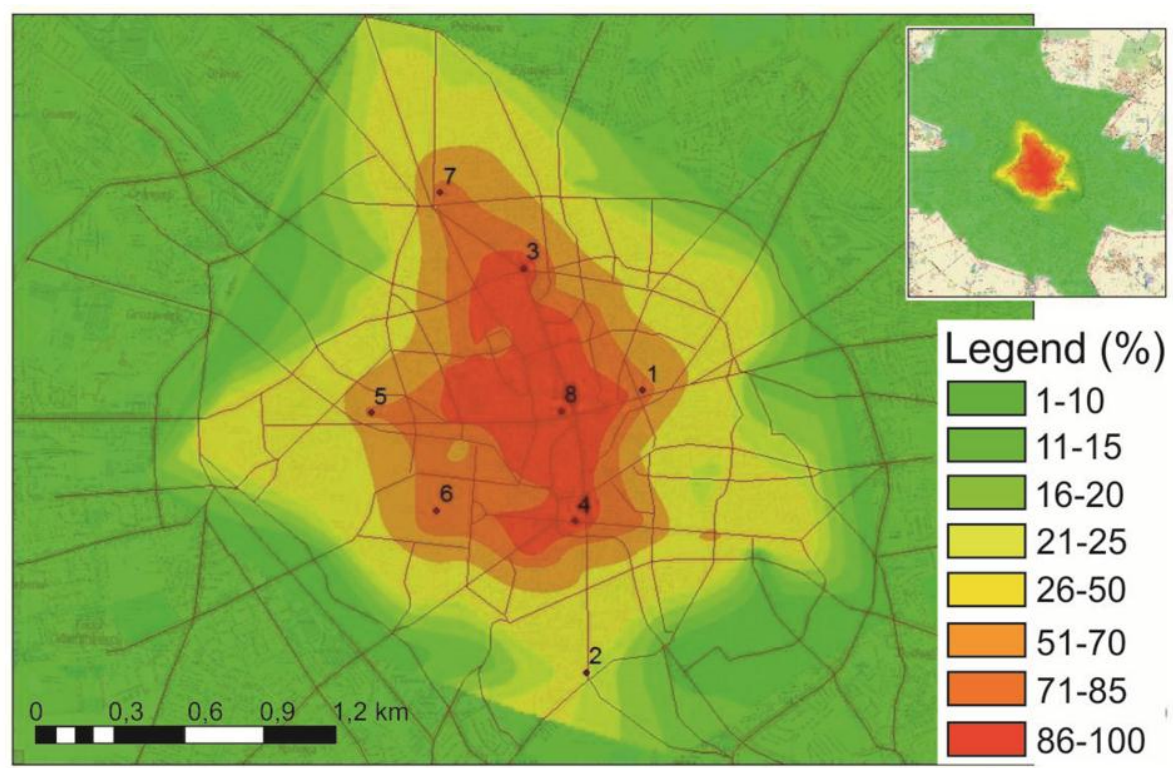

Figure 1. Cognitive map of Bucharest city`s centre; 1. Armenească Church, 2. Gheorghe Şincai Lyceum, 3. Piața. Romană, 4. Piaţa. Unirii, 5. Opera Română, 6. Parliament's Palace, 7. Piaţa. Victoriei, 8. Universitatea din București. 
the structural-mental axes that converge towards the city's central nucleus.

The non-axial landmarks are located between major arteries and represent well-known elements but which are not sufficiently visible. Still they have the ability to imprint on the adjacent space the values of a personal image. The duality of the two types of landmarks is the feature that contributed to shaping the urban centre. The greater centrality value of certain landmarks helped to identify and contour the city's nucleus area, where landmarks transcend this state by becoming symbols of the city, meaning elements which assign emotional value to this territory through the memorial image.

Should the geometric centre of Bucharest be considered the intersection of north-south (Nicolae Bălcescu Boulevard) and west-east axes (Regina Elisabeta Avenue), then we would notice an uneven shaping of the centre in regard to these two. However the city's nucleus largely conserves the mental construct of Bucharest's urban population from the '7os. It's more developed further into the west as opposed to the north-south axis and less in the east side of the city. This demarcation of the central nucleus is also present in the present perception of the residents. Delineating the other two rings of centrality in relation with the north-south axis and west-east revealed several changes compared with the previous analyses of people's perception. Thus, the centre's limits are not so equal in regard to the major axes, as they appeared in the '7os collective image. Currently the central area has a vast expansion in the west compared to the north-south axis (encompassing Piaţa. Operei in the west) and towards east it reaches, along the west-east axis, the intersection between Calea Moşilor and Pache Protopopescu Boulevard.

The analysis of the collective imagination construct of Bucharest's inhabitants reflects wider processes that have occurred during the configuration of the "Civic Centre" and which deeply marked it. The new created axis across Bucharest's landscape (since 1980, on a west-east direction) is a visual rupture. It has a limited variation of the urban composition, of building volumes, which inoculates a monotonous repetition that generates dysfunctions in perceiving distances. There is also an axial dissolution of the mental distance considering that major landmarks are reduced to very few items which have an easy legibility. This axis is similar to a corridor that is structured by a visual support: the Parliament's Palace (previously called "Casa Poporului" /"People's House") which is a monumental building but relatively isolated in relation to the city's older urban structure in which it was inserted. In terms of the collective mental construct, the space which was affected by reconfiguring through the creation of the Parliament's Palace changed in the perception from a space located outside the central nucleus of the city, to a space that is embedded in the central area of the city as a prominence.

Within this space, centrality extends along the axis known as Splaiul Unirii as an elongated prominence which also contours islands of centrality (e.g. the intersection of streets Nerva Traian and Splaiul Unirii). In comparison with the cognitive maps of the centre that were created in the '70s, I observed that simultaneously with the reconfiguration of the central area it also appeared a change in the mental and behavioural representation of this place. It reflects within the extending centrality into east-west, against the north-south axis which is imposing a compression process south of Piaţa. Unirii (where the centre area's limit contracts from Parcul Tineretului to the south of the church Sf. Spiridon Nou). Another area that has undergone changes in comparison to the cognitive maps of the '7os is Gara de Nord rail station and its surroundings which were no longer included in the central area of the city as a prominence.

Damian (1973) exemplified in the '7os the relativity of the centre's limits depending on the respondent's location, assuming that a landmark's centrality is influenced by the observer's perspective. Thus, the author identified two types of landmarks: 1) "proximal landmarks" that are in close proximity to the evaluator, 2) "distant landmarks" which are found in locations that are opposite to the evaluator.

Figures 2-4 indicate the cartographic representation at the neighbourhoods level of the results that were obtained during the sociological survey revealed a differenced centre's expansion, depending on the social profile of these urban structures. The aim of this approach was to observe how the urban centre is being modelled, based on the perception of communities from Bucharest neighbourhoods. It was considered that the centrality of proximal landmarks, as indicated by the observer located in a particular neighbourhood, is greater than the total estimation of the entire statistical sample while the centrality of distant landmarks is smaller (Damian, 1973). The only stable landmarks both in the case of total respondents and that of certain neighbourhoods are those located in the urban centre's nucleus.

In previous studies I observed that as for the inner identity of Bucharest, there is a distinction between centre and periphery which is observable in the urban tissue, but there is also a delineation that is perceived by the socio-spatial structures. Bucharest, since its initial construction, development a gap between its northern and southern parts, a gap that can be easily seen on the centre's mapping (Stoiculescu \& Huzui, 2011). 


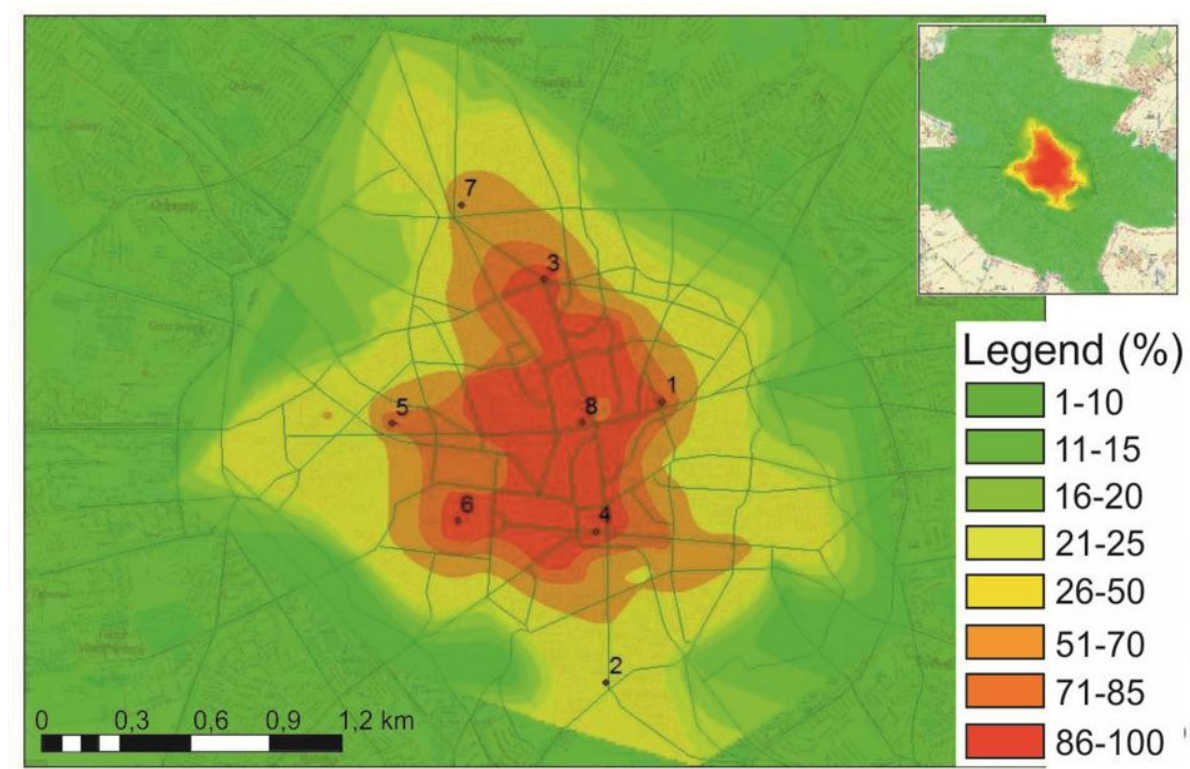

Figure 2. The centre's delineation, according to respondents from Titan neighbourhood, 1) Armenească Church, 2) Gheorghe Şincai Lyceum, 3) Piaţa. Romană, 4) Piaţa. Unirii, 5) Opera Română, 6) Parliament’s Palace, 7) Piaţa. Victoriei, 8) Universitatea din București.

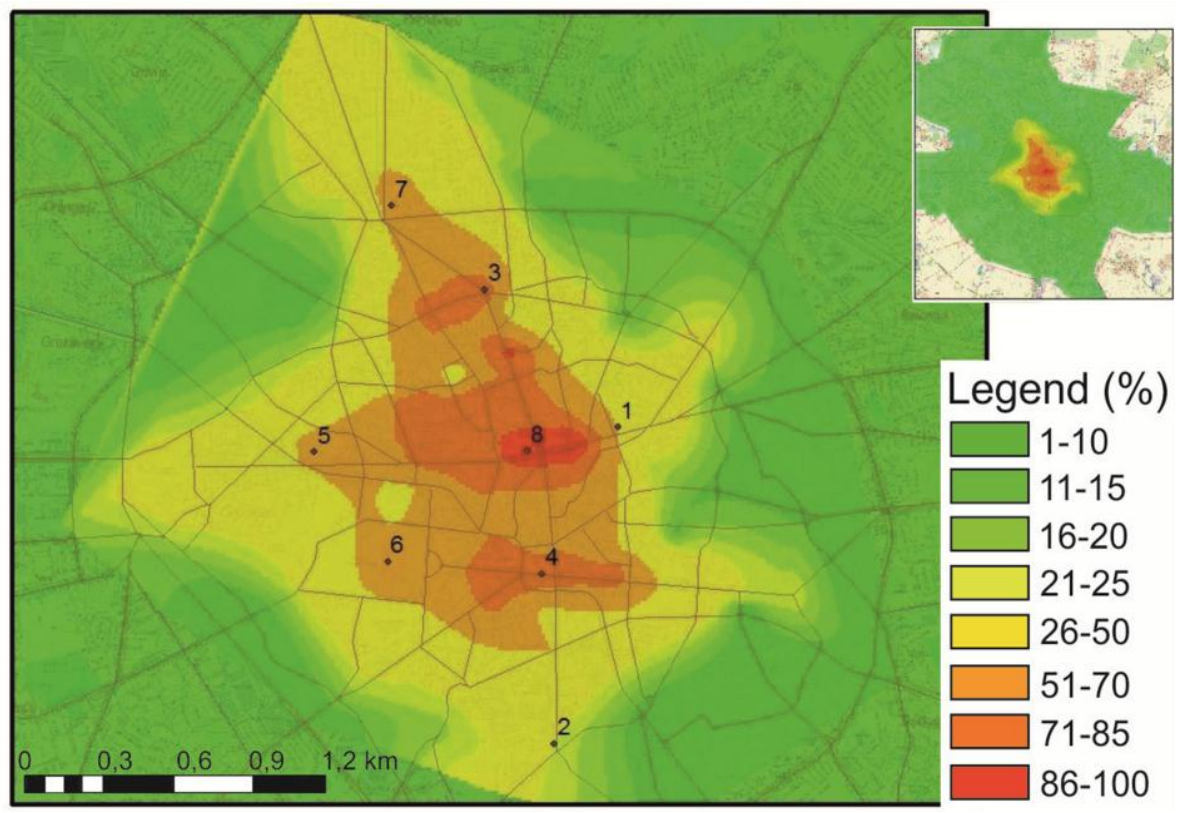

Figure 3. The centre's delineation, according to respondents from Ferentari and Rahova neighbourhoods, 1) Armenească Church, 2) Gheorghe Şincai Lyceum, 3) Piaţa. Romană, 4) Piața. Unirii, 5) Opera Română, 6) Parliament’s Palace, 7) Piața. Victoriei, 8) Universitatea din București.

North includes, because of the urban planning model (parcels and parks which were created during the interwar period, large spaces and generous homes, separated by wide streets and many road alignments), elements which may be assigned with the centrality attribute (architectural objectives, public institutions, features of urban tissue). In contrast, south of the city has a profile of rural antecedence overlapped by blocks alignments that are located along major traffic arteries that become narrow and suffocated, which limits the potential of expanding of the urban centrality.

As for the major urban habitats (Balta Albă-Titan, Drumul Taberei) it was observed that there is a constant series of landmarks indicating the central nucleus of the city because this large habitats were included in an urban project that was synchronized with the socialist construction of the "civic centre". Respondents from these neighbourhoods include the new urban axis (with the Parliament's Palace) in the 


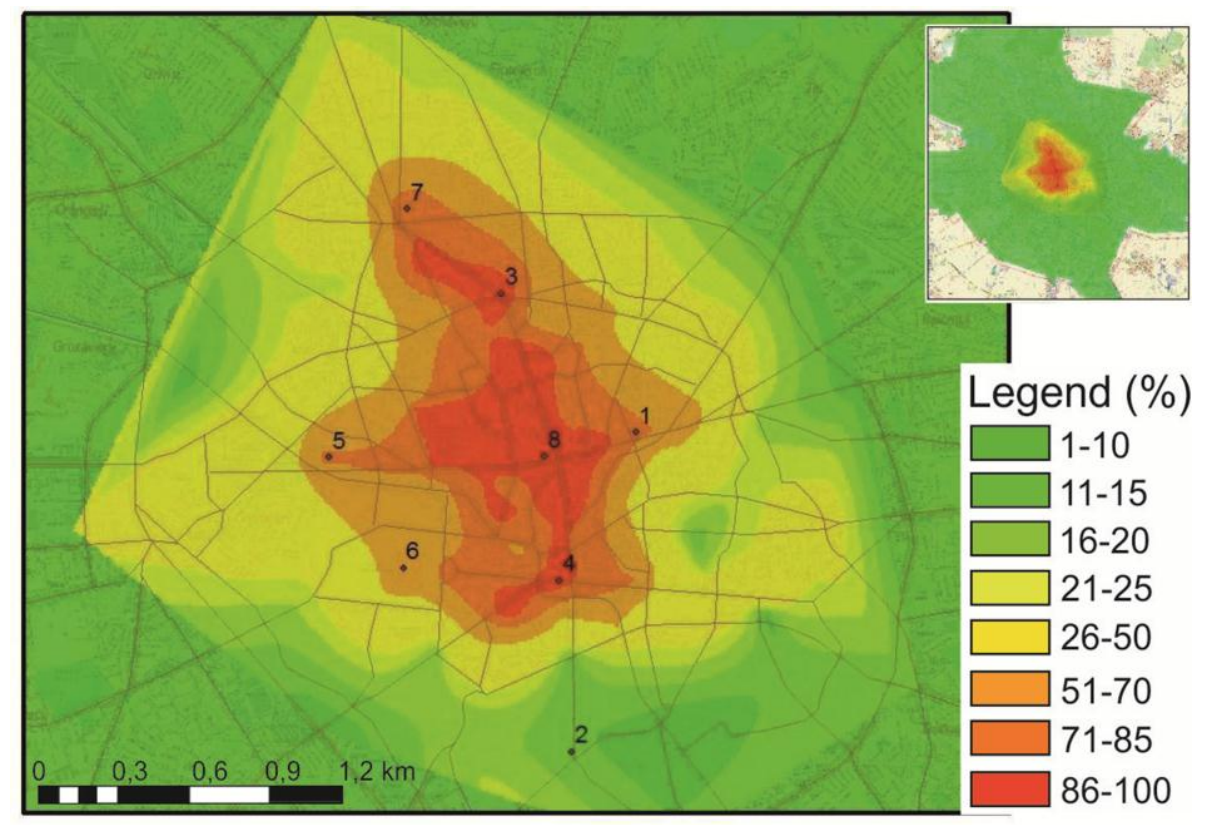

Figure 4. The centre's delineation, according to respondents from the northern neighborhoods, 1) Armenească Church, 2) Gheorghe Șincai Lyceum, 3) Piața. Romană, 4) Piața. Unirii, 5) Opera Română, 6) Parliament's Palace, 7) Piaţa.

Victoriei 8) Inniversitatea din Rucurecti

centre's nucleus and they mentally join it to the historical centre (Figure 2).

The minimum extension of the central nucleus is associated with respondents from neighbourhoods characterized by visible elements of rurality in which were inserted multi-family social housing units (Ferentari and Rahova). In the general mental construct these neighbourhoods have a repulsive character (Bulai, 2011) and from a social perspective there is a self-isolation of members from these communities in relation with the rest of the city. This indicates a limited cognitive construction which is shaped as a central nucleus restricted to areas around Pța. Universităţii and Cinema Patria. This is reflected by the large share of responses like "I do not know the landmark" or "I do not know if it's in the centre" (Figure 3).

Neighbourhoods from the city's northern side express an extended centrality beyond Piaţa Victoria and south of Piaţa Universităţii which is profiling as a large prominence that includes Dealul Mitropoliei. It also has an unbalanced character on the north-south longitudinal axis compared with the transverse landmarks' values from the east-west axis, thus the central nucleus has a translation tendency towards the northern part of the capital (Figure 4).

The previous figures showed how the city's centre limit varies in shape due to the importance of the landmarks which are located along major street axis thus being more visible within daily routes. The centre's shape tends to dilate towards the northern part of the city, the causes including the function of the landmarks which is established and recognised in historical time. The maps of Bucharest's city centre indicate that the perception of its limits and extent changes in relation to the respondent's neighbourhood. The most significant distortion of the centre's nucleus is correlated to respondents living in Rahova and Ferentari neighbourhoods who aren't very familiar with the central part of the city and otherwise important landmarks and not recognised by this group. The centre's prominences are elongated towards the neighbourhoods due to the cognitive reduction of the distance between residence and the perceived centre. This study revealed an arrangement of landmarks which shaped the urban centre along the major traffic arteries that functioned as the city's early development axes and connectivity with the rest of the country. Their importance within the territorial context transposes on the continuity of perceiving the north-south and north-west axes to encompass the city's nucleus between Piaţa Victoriei and the Parliament's Palace. For Bucharest, it contours a cognitive structuring of the centre in terms of historical conditioning. The general trajectory of the perceived centre after the change of political regime is directed towards the north of the city which condenses the main landmarks. The Parliament's Palace (formerly "Casa Poporului") is at the top of the north-south axis and represents an isolated element that emerged through a complex spatial-symbolic process of dismantling through the removal or destruction of a pre-existing pattern. It appears as an imposed element which became after 1990 an assumed one, perceived as an element of brand rather than one of identity. 


\section{Conclusions}

The implication of these findings are structured on three levels: 1) in theory, the method which was used in this paper appeals to the respondent's memory regarding Bucharest in order to associate the centrality attribute to certain landmarks. Given the questionnaire's complexity, the statistical sample of respondents is characterised by high education, employment and familiarity with the city. This gives way to the perspective of continuing the study on a larger sample of residents with different demographic features; 2) the utility for urban planning resides from the comparison of development politics with the residents' perception of the centre. Thus, the study draws attention on the spaces between major axes which are not well defined and should be better integrated in politics regarding the centre's planning. Moreover the west-east axis (Parliament's PalaceAlba Iulia) includes few legibility elements, in opposition to the urban perspective of the General Urban Plan. Finally, the current policy of dividing the centre's administration between five of Bucharest's sectors could be changed in order to consider the centre as a unique entity that should be managed coherently; 3) once identified, the city centre could be better managed in order support the residents' identity who relate to the urban space. Thus, the centre becomes a space of social condensation which translates the collective processes of identity modelling. Any major intervention in the city's centre has repercussions on the perception of the spatial configuration.

\section{References}

Bailly, A 1977, La perception de l'espace urbain, les concepts, les méthodes d'étude, leur utilisation dans la recherche urbanistique, Centre de recherche d'urbanisme, Paris.

Bailly, A \& Béguin, H 1982, Introduction à la geographie humaine, Editura Armand Colin, Paris.

Bailly, A \& Scariati, R 1990, L'humanisme en géographie, Editura Anthropos, Paris.

Boncu, Ş 2008, Psihologia mediului, note de curs, Facultatea de Psihologie şi Ştiințe ale Educației, Modulul de Psihopedagogie Socială, Iaşi.
Buică, C, Popescu, M \& Tomescu O 1995, 'Bucureștiul văzut de Bucureșteni. Reprezentări speciale ale spaţiului urban', Revista de Cercetări Sociale, 3, p.111-115.

Bulai, A 2011, Cartografierea socială a Bucureștiului, S.N.S.P.A, Facultatea de Ştiinţe Politice, Departamentul de Sociologie.

Damian, L 1973, 'Centrul Bucureștiului: unele aspecte psihologice', Arhitectura, no. 4, p.13-14.

Damian, L, Popescu-Criveanu, Ş \& Paneiu, L 1976, 'Aspectele imaginii populaţiei despre centrul oraşului București', Viitorul social, vol. V, no. 4, p. 652-663.

Lynch, K 1960, The Image of the City, MIT Press, Cambridge MA.

Macavescu, M 1973, 'Inima Oraşului', Arhitectura, no. 4, p. 12-13.

Moser, G 2009, Introducere în psihologia mediului, Editura Polirom, Bucureşti.

Niţu, C \& Crăciunescu, V 2009, Modele digitale altimetrice şi geostatistică, available http://earth.unibuc.ro/download/modele-digitalealtimetrice-si-geostatistica.

Ostermann, F 2009, Modelling, analyzing and visualizing human space appropriation, Zürich University, available at

http://www.geo.uzh.ch/microsite/nfp54/docs/ostermann _dissertation.pdf.

Pascariu, G 2006, Zona centrală în marile orașe, note şi suport de curs, an IV, UAUIM.

Rengert, FG \& Pelfrey, VWJr. 1997, 'Cognitive mapping of the city centre: comparative perceptions of dangerous places', in D Weisburd \& $\mathrm{T}$ McEwen (eds.) Crime Prevention Studies, vol. 8, Lynne Rienner Publishers, 193217.

Sandu, MA 200o, Planul Urbanistic General al Municipiul București, Mapa 3, Interpretarea Opțiunilor Populaţiei.

Seaman, D 2008, 'Place and Placelesness in Edward Relph, 1976', in P Hubbard, R Kitichin \& G Valentine (eds.), Key texts in Human Geography, Sage Publications.

Stoiculescu, R \& Huzui, A 2011, 'Community's landscape identity, an instrument for development in continuity, the case of Bucharest municipality and Sinaia town', Geographica Timisiensis, vol. 20, no. 2, p.57-66.

Tallon, RA \& Bromley, DFR 2004, 'Exploring the attractions of city centre living: evidence and policy implications in British cities', Geoforum, no. 35, p. 771-787.

Tuan, YF 2002, Space and Place: The Perspective of Experience, Minneapolis, University of Minnesota Press. 